\title{
ANALISIS SPASIAL PERUBAHAN GARIS PANTAI DI PESISIR KABUPATEN SUBANG, JAWA BARAT
}

\author{
(Spatial analysis of shoreline changes in the coastal area of Subang District, West Java)
}

\author{
Ankiq Taofiqurohman ${ }^{1}$ dan Mochamad Furqon Azis Ismail ${ }^{2}$ \\ ${ }^{1}$ Fakultas Perikanan dan Kelautan, Universitas Padjadjaran, Bandung, Jawa Barat. \\ ${ }^{2}$ Pusat Penelitian Oseanografi, Lembaga Ilmu Penelitian Indonesia.
}

\begin{abstract}
Pengamatan mengenai perubahan garis pantai di pesisir Kabupaten Subang, Jawa Barat telah dilakukan dengan menggunakan program Digital Shoreline Analysis System berdasarkan citra satelit Landsat TM dari tahun 1996-2010. Tujuan dari penelitian ini adalah untuk mengetahui besar perubahan garis pantai di Kabupaten Subang serta zonasi kawasan yang mengalami perubahan garis pantai tersebut. Metode yang digunakan adałah pemprosesan citra dan survey lapangan. Hasil dari penelitian ini menunjukkan bahwa dari tahun 1996-2010 perairan pesisir Kabupaten Subang mengalami perubahan garis pantai oleh adanya akresi dan abrasi yang maksimalnya sejauh lebih dari $1 \mathrm{~km}$. Hasil analisis regresi antara perubahan waktu dengan akresi serta abrasi memberikan nilai positif. Secara keseluruhan, lebih dari 50\% panjang pesisir Kabupaten Subang dikategorikan dalam kerusakan yang parah. Perubahan garis pantai di Pesisir Kabupaten Subang terjaditerutama karena kegiatan pembangunan di sekitar pesisir seperti pembukaan lahan mangrove menjadi támbak dan sawah, pembangunan pemukiman, serta transpor sedimen dari sungai-sungai di kawasan pesisir Kabupaten Subang.
\end{abstract}

Kata kunci: perubahan garis pantai, Kabupaten Subang, citra satelit, ak̂resi, abrasi.

Observation of coastal shoreline changes in the Subang Distriet was conducted using Digital Shoreline Analysis System Program based on the satellite images of Landsat TM from 1996 to 2010 . The purpose of this study was to determine the distance of shoreline change and the zoning area in the Coastal of Subang District. Methods used in this study were images processing and field survey. The results of the study indicated the presence of shoreline changes which experienced maximum accretion and abrasion of more than $1 \mathrm{~km}$ between 1996 to 2010 . The results of regression analysis between time and accretion as well as time and abrasion showed positive correlation. More than 50\% the coastalarea of Kabupaten Subang was in severely damaged condition. Coastal shoreline change in Kabupaten Subang oceurred mainly due to the developmental activities such as residential construction, coastal mangrove conversion to ponds and rice paddies and sediment transport from the river around Kabupaten Subang.

Keywords: shoreline change, Subang District, satellite images, accretion, abrasion.

PENDAHULUAN

Pemanfaatan kawasan pantai utara Jawa Barat untuk menunjang kegiatan ekonomi dan pembangunan nasional menimbulkan kerusakan pada wilayah pesisiy. Kerusakan tersebut meliputi abrasi, akresi dan intrusi air laut. Salah satu kawasan pantai utara yang mengalami kerusakan akibat pemanfaatan wilayah pesisir adalah Kabupaten Subartg Jawa Barat. Hasil kajian dalam studi regional yang dilakukan Badan Perencanaan Pembangunan Daerah Provinsi Jawa Barat (2007) menunjukkan adanya kemunduran pantai seluas 392,32 ha/tahun dari tahun 1995 sampai dengan 2001, sedangkan tahun 2001 sampai dengan 2003 terjadi kemunduran pantai sekitar 370,3 Ha/tahun.

Kabupaten Subang secara geografis terletak di bagian utara Provinsi Jawa Barat yaitu $107^{\circ}$ $31^{\prime}-107^{\circ} 54^{\prime}$ BT dan $6^{\circ} 11^{\prime}-6^{\circ} 49^{\prime}$ LS. Luas wilayah Kabupaten Subang adalah 205.176,95 ha atau
6,34\% dari luas Provinsi Jawa Barat saat ini dengan ketinggian antara $0-1500 \mathrm{~m}$ dpl. Secara administrasi Kabupaten Subang terdiri dari 22 kecamatan, 244 desa dan 8 kelurahan. Dari seluruh kecamatan yang ada, terdapat 4 kecamatan yang merupakan kecamatan pesisir, yaitu Kecamatan Blanakan, Sukasari, Legon Kulon dan Pusakanagara. Luas wilayah kecamatan pesisir Kabupaten Subang adalah $333,57 \mathrm{~km}^{2}$ atau $16 \%$ dari luas kabupaten (BAPPEDA Jabar, 2007).

Proses geodinamika yang terjadi di sepanjang pesisir dan laut Kabupaten Subang, menimbulkan perubahan garis pantai. Abrasi hampir terjadi di sepanjang pantai yang diperparah dengan kerusakan hutan mangrove yang diubah menjadi areal tambak. Beberapa pantai di Kabupaten Subang telah mengalami abrasi seperti yang terjadi di Muara Karang-Legon Wetan hingga Pondok Bali, juga di sepanjang daerah Patimban. Sedimentasi terjadi di beberapa muara sungai dengan adanya delta- 
delta sungai akibat munculnya tanah timbul di sepanjang pantai. Intrusi air laut terjadi terutama di daerah pantai yang relatif datar (Saskiartono, 2008).

Teknologi yang mudah dan cepat untuk pemantauan perubahan garis pantai adalah dengan menggunakan teknologi penginderaan jauh melalui perekaman citra satelit sebagai datanya. Salah satunya adalah dengan menggunakan data hasil perekaman citra Landsat (Land satellite). Sensor yang digunakan adalah Thematic Mapper (TM) yang memiliki resolusi spasial $30 \times 30 \mathrm{~m}$. Sensor ini terdiri dari 7 band yang memiliki karakteristik berbeda-beda sesuai dengan kebutuhan (Lillesand and Kiefer, 1994). Data Landsat dipilih karena mudah didapatkan. Tujuan dari penelitian ini adalah untuk mengetahui seberapa besar pergerakan dari garis pantai di Kabupaten Subang dengan memanfaatkan citra satelit Landsat. Daerah kajian difokuskan kepada daerah yang diketahui telah mengalami sedimentasi dan abrasi (Gambar 1).

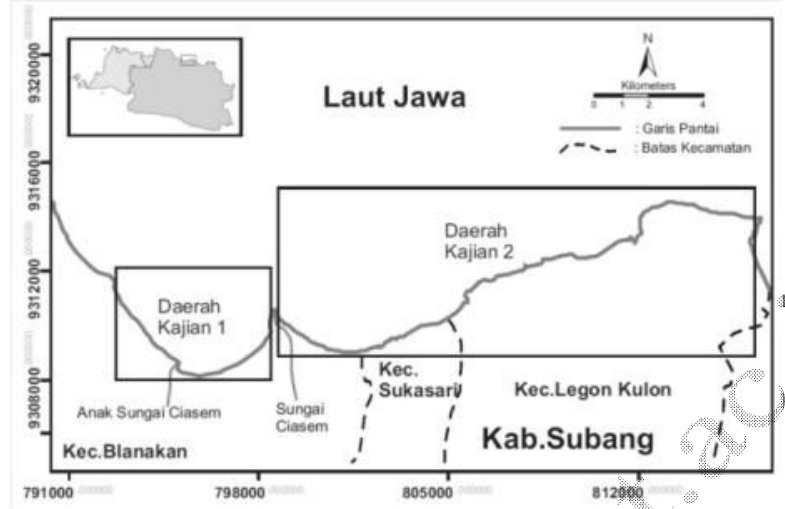

Gambar 1 Wilayah kajian di pesisinKabupaten Subang, Jawa Barat.

Figure 1. Study areas in coast of Sybang Regency, West Java.

\section{METODEPENELITIAN}

Metode yang digunakan dalam penelitian ini adalah metode survei dengan analisis deskriptif kuantitatif. Pengolahan data yang dilakukan meliputi:

\section{Pengorganisasian data}

C. Data yang dipilih dari citra Landsat tahun $1996-2010$ terbebas dari awan dan satu citra yang mewakili satu tahun. Citra Landsat yang mengalami striping dikoreksi dengan menggunakan program Frame and Fill, kemudian dipisahkan antara darat dan laut (masking). Hasil masking di digitasi menjadi data vektor dari garis pantai dan dikoreksi terhadap pasut. Koreksi pasut dilakukan dengan mengambil surut terendah dari waktu seluruh perekaman data citra. Terakhir, dilakukan tumpang susun data vektor berdasarkan urutan tahunnya.

\section{Perhitungan perubahan garis pantai}

Perhitungan perubahan garis pantai menggunakan metode dari Thieler et al. (2008) yang menghitung jarak antar vektor garis pantai setiap tahun, agar diketahui pergerakan total garis pantai. Perhitungan ini memanfaatkan transek-transek sebagai acuan dari perubahan garis pantai. Tiap transek ini berjarak 30 meter, dengan asumsi 1 transek mewakili 1 piksel citra Landsat (gambar 2). Perhitungan garis pantai ini menggunakan program Digital Shoreline Analysis System. Transek untuk pengamatan dipilih yang menunjukkan perubakan garis pantai yang terjauh (transek maksimal) dan yang terdekat (transek minimal). Perhitungan regresi linear antara jarak perubahan garis pantai dengan perubahan tahun, dengan garis pantai pada tahun pertama (1996) dijadikan sebagai titik awal perhitungan jarak (bennjłai nol).

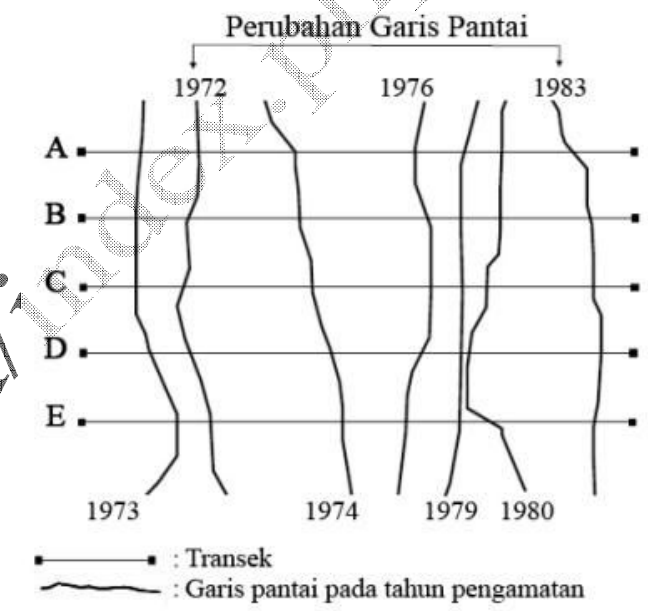

Gambar 2. Ilustrasi perhitungan menggunakan program Digital Shoreline Analisis System.

Figure 2. Illustration of calculation using Digital Shoreline Analisis System software.

\section{Tingkat kerusakan}

Penentuan tingkat kerusakan pantai didasarkan kepada klasifikasi dari Litbang PU Pengairan tahun 1993 (Setyando dan Triyanto,2007), yaitu berdasarkan jarak kemunduran garis pantai sebagai berikut:

- Amat sangat berat : $>10 \mathrm{~m} /$ tahun;

- Amat berat : :5,0-10,0 m/tahun;

- Berat : $2,0-5,0 \mathrm{~m} /$ tahun;

- Sedang : : $0,5-2,0 \mathrm{~m} /$ tahun;

- Ringan $:<0,5 \mathrm{~m} /$ tahun.

\section{HASIL DAN PEMBAHASAN}

\section{Daerah kajian 1}

Daerah kajian 1 berada di pesisir Kecamatan Blanakan, tepatnya di bagian Teluk Blanakan sebelah barat. Perubahan garis pantai yang terjadi 
menunjukkan adanya pergerakan maju dari garis pantai, yang mengindikasikan terjadinya akresi (Gambar 3). Akresi yang terjadi pada daerah kajian 1 disebabkan oleh adanya limpasan sedimen dari Sungai Ciasem yang kemudian didorong oleh arus sejajar pantai yang menuju ke arah barat. Hal tersebut terkonfirmasi dari windrose hasil perekaman data tahun 1996-2010 di pantai utara Subang yang menunjukkan adanya dominasi angin menuju ke arah barat dan barat daya (Gambar 4). Sedimen yang berasal dari Sungai Ciasem tersebut kemudian terperangkap di teluk Kecamatan Blanakan.

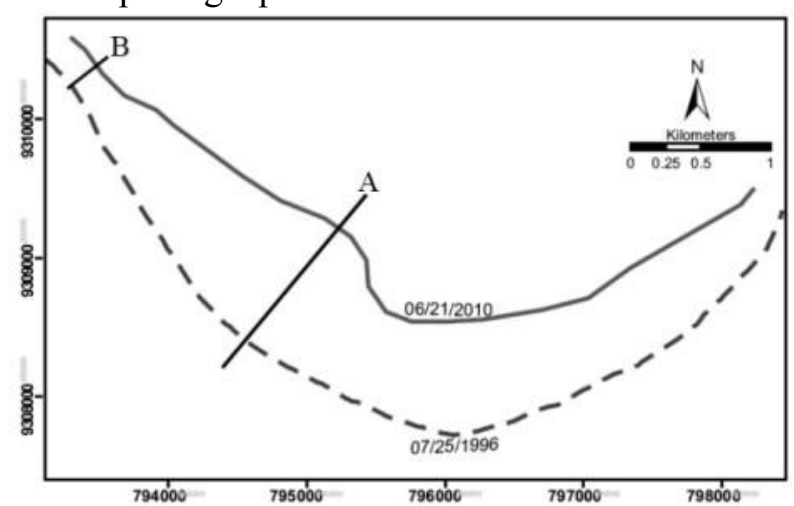

Gambar 3.Daerah Kajian 1.

Figure 3. Study site 1.

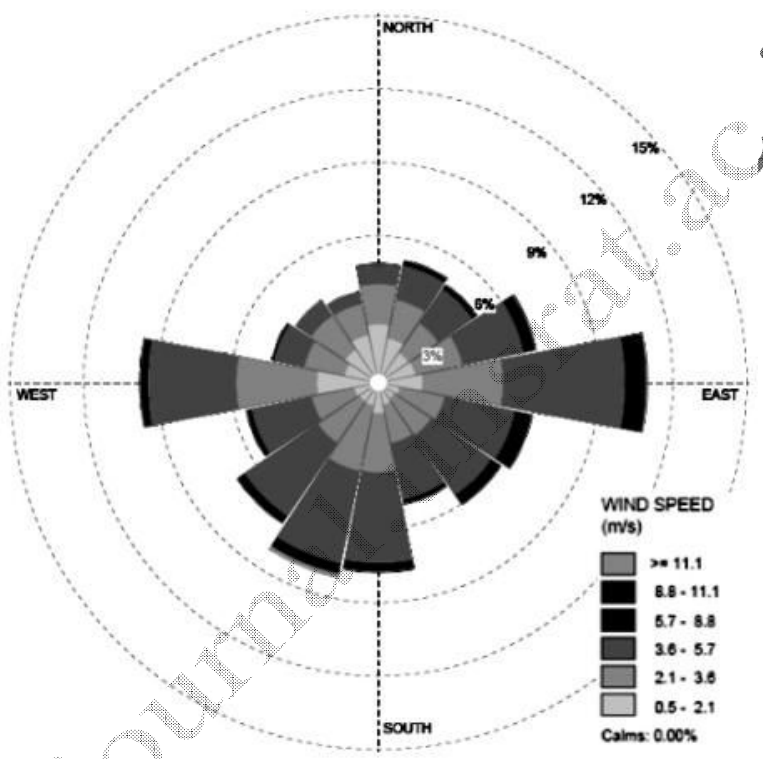

Gambar 4.Windrose daerah pesisir Kabupaten 2) Subang.

Figure 4 Windrose of coastal area of Subang Regency.

Dari transek-transek hasil perhitungan yang dibuat, didapatkan nilai rata-rata secara keseluruhan kemajuan garis pantai di daerah kajian 1 dari tahun 1996 sampai dengan 2010 adalah sebesar $686,53 \mathrm{~m}$, dengan rata-rata kemajuan tiap tahunnya adalah 49,04 m. Kemajuan paling besar ada pada transek A, yaitu sebesar 1051,55 m (Gambar
5), sedangkan kemajuan paling kecil terjadi pada transek B, yaitu sebesar 229,52 m (Gambar 6). Kemajuan garis pantai paling besar terjadi oleh karena pada bagian tersebut merupakan sisi bagian dalam dari teluk di pesisir Kecamatan Blanakan dan terdapat muara anak Sungai Ciasem, sehingga memperparah terjadinya sedimentasi.

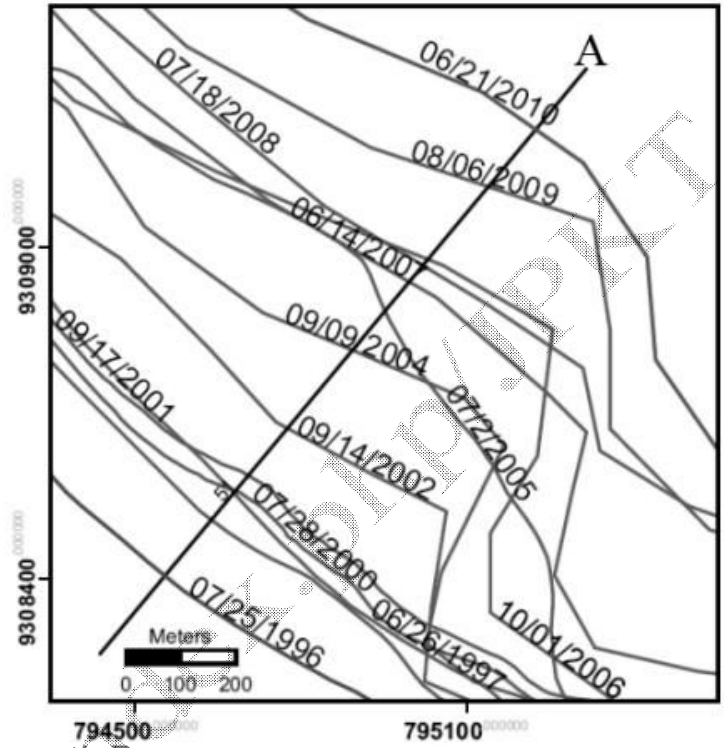

Gambấ F. Transek A.

Fidure 5. Transect A.

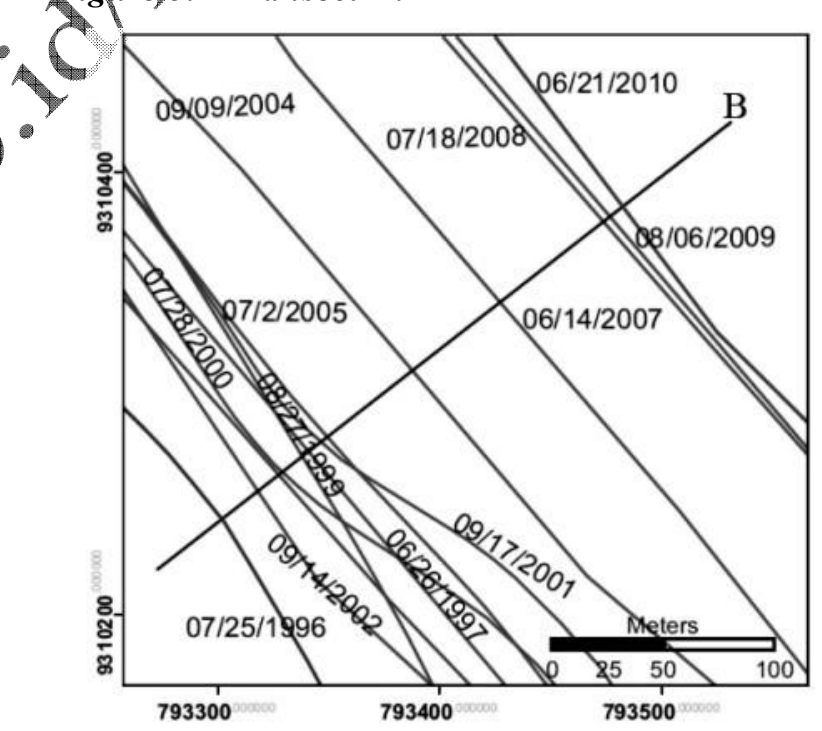

Gambar 6. Transek B.

Figure 6. Transect B.

Hasil regresi antara pertambahan tahun dengan perubahan garis pantai pada transek yang mewakili keadaan akresi maksimum (transek A) dan minimum (transek B), memperlihatkan korelasi positif yang sangat tinggi (Gambar 7 dan 8), ini menunjukkan bahwa akresi yang terjadi di teluk Pantai Blanakan bertambah secara linier dan stabil. Daerah akresi yang terbentuk di teluk Kecamatan Blanakan berfungsi menjadi kawasan hutan mangrove. 


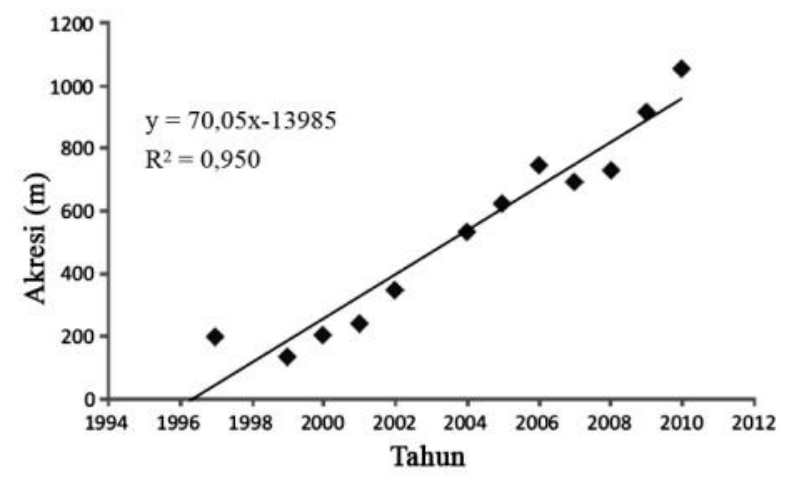

Gambar 7. Regresi linear pada transek A. Figure 7. Linear regression in transect $A$.

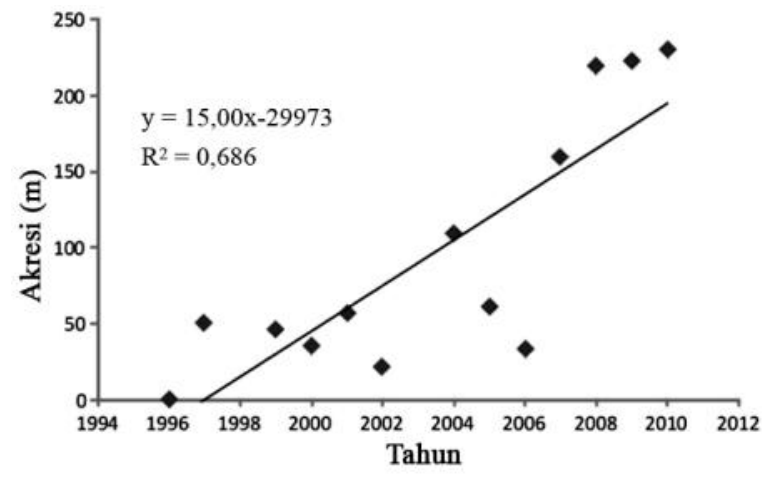

Gambar 8. Regresi linear pada transek B.

Figure 8. Linear regression in transect $B$.

\section{Daerah kajian 2}

Daerah kajian 2 meliputi sebagian Kecamatan Blanakan, Sukasari dan Legon Kulon. Ga- 。 ris Pantai di daerah kajian 2 menunjukkan kemud duran setiap tahun (Gambar 9). Kemunduran atau abrasi di Pesisir Subang terjadi karena berkerangnya luas hutan mangrove, seperti yangterjadi di Kecamatan Sukasari dimana terjadit proses abrasi yang mendominasi seluruh wilayah pesisir kecamatan tersebut pada rentang waktu 2001 sampai dengan 2011 (Vina et al. 201)). Menurunnya kerapatan populasi hutan hangrove telah mengurangi fungsinya sebagai penakan gelombang sehingga abrasi sulit untuk ditahan. Faktor utama yang menyebabkan pefurunan kerapatan populasi mangrove adalah âdanya konversi kawasan hutan mangrove menjadiperuntukan lain seperti tambak ikan dan ủdang, pemukiman dan kawasan industri secaratidak terkendali. Terjadinya tumpang tindih pemanfaatan kawasan hutan mangrove untuk berbagai kegiatan pembangunan juga merupakan penyebab dari rusaknya hutan mangrove di wilayah Subang (BAPPEDA Jabar, 2007).

Rata-rata abrasi yang terjadi secara keseluruhan di daerah kajian 2 selama kurun waktu 14 tahun adalah sebesar 565,63 meter, dengan ratarata kemunduran garis pantai tiap tahun adalah 40,4 m. Abrasi maksimal terjadi pada transek C di pesisir Desa Mayangan (Gambar 11), Kecamat- an Legon Kulon, yaitu sejauh 1.206,83 m. Hal ini kemungkinan karena kerapatan pohon mangrove di pesisir ini adalah yang terkecil, yaitu sebesar 33 pohon/ha (Novianty et al. 2011), sedangkan abrasi minimal di transek D (Desa Anggasari, Kecamatan Sukasari) yaitu sebesar 53,17 m (Gambar 12). Abrasi menyebabkan banjir air laut ( $r o b)$ di beberapa desa, seperti di Desa Mayangan, Kecamatan Legon Kulon (Gambar 10).

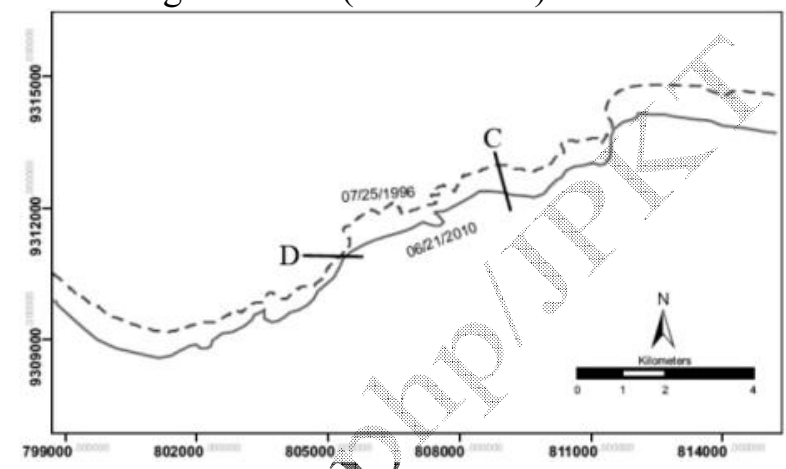

Gambar 9. Daerah kajián 2.

Figure 9. Study Site 2..'

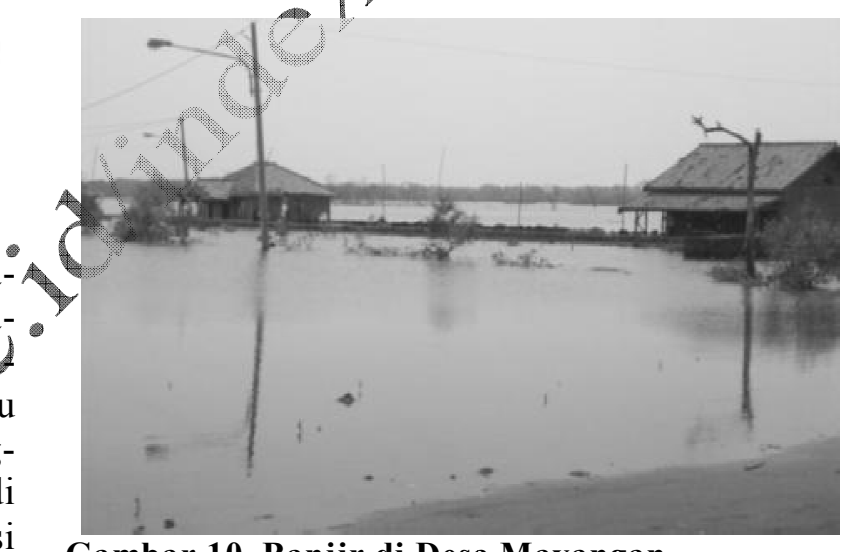

Gambar 10. Banjir di Desa Mayangan.

Figure 10. Flood in Mayangan village.

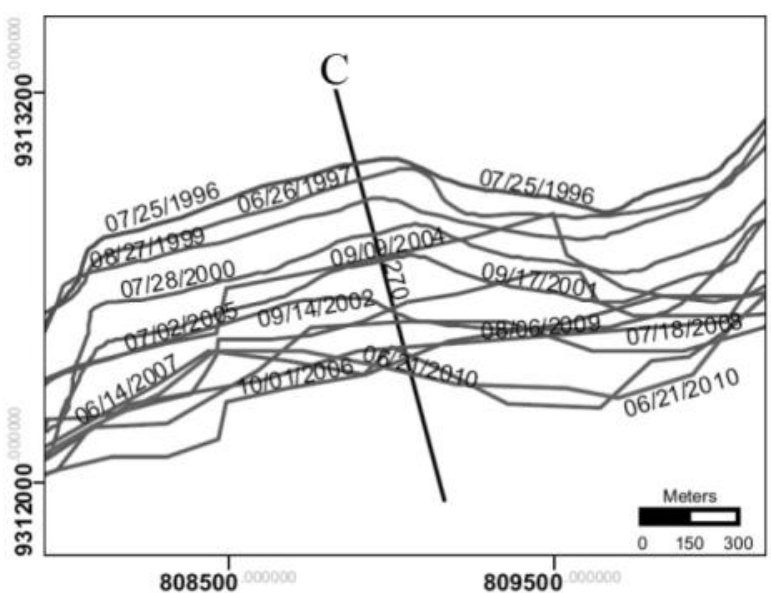

Gambar 11. Transek C.

Figure 11. Transect $C$.

Hasil regresi antara kemunduran garis pantai terhadap perubahan tahun ditunjukan pada Gambar 13 dan 14 pada dua transek yang mewakili ke- 
adaan abrasi maksimal (transek C) dan abrasi minimal (transek D). Kedua gambar tersebut memperlihatkan adanya korelasi yang tinggi untuk transek $\mathrm{C}$ dengan nilai $\mathrm{R}^{2}$-nya adalah sebesar 0,89 , sedangkan untuk transek $\mathrm{D}$ nilai $\mathrm{R}^{2}$-nya adalah 0 , artinya tidak ada hubungan jarak abrasi dengan pertambahan tahun, atau dapat diasumsikan bahwa abrasi tidak berpengaruh pada transek D. Hal ini terjadi karena transek D berada di Desa Anggasari yang mempunyai kerapatan mangrove cukup tinggi yaitu 1.271 pohon/ha (Novianty et al. 2011).

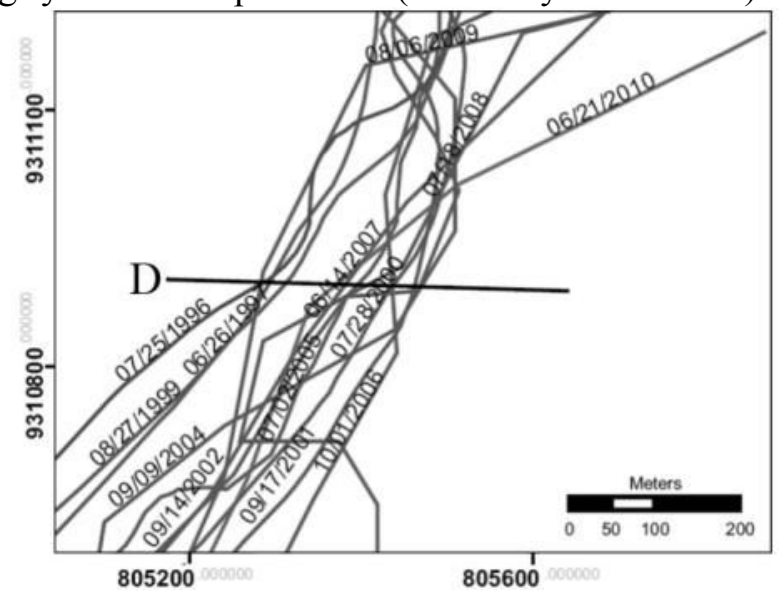

Gambar 12. Transek D.

Figure 12. Transect D.

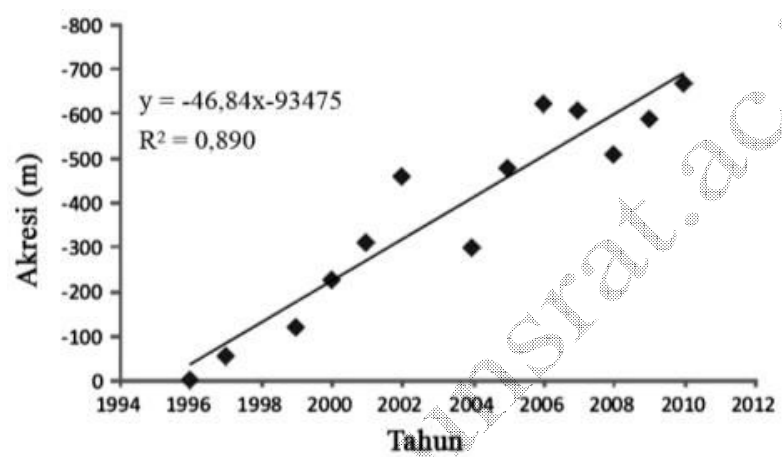

Gambar 13. Regresi hnear pada transek C.

Figure 13. Linear regression in transect $C$.

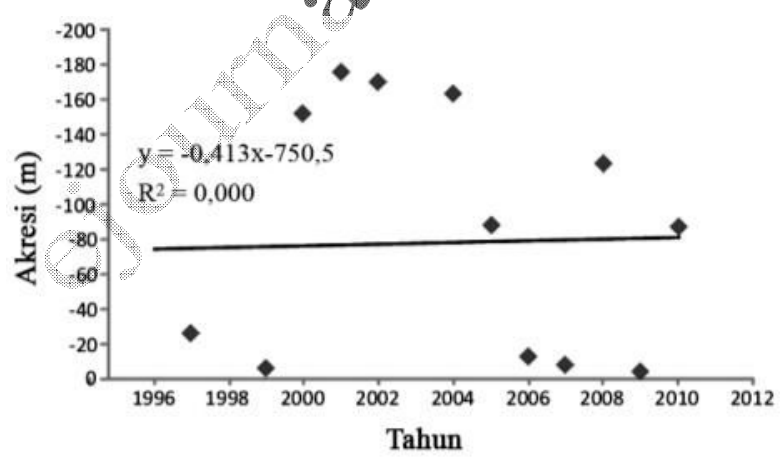

Gambar 14. Regresi linear pada Transek D.

Figure 14. Linear regression in transect $D$.

\section{Tingkat kerusakan}

Berdasarkan pergeseran garis pantai di pesisir Kabupaten Subang selama kurun waktu 1996 sampai dengan 2010, sebagian besar dari pesisir, mengalami tingkat kerusakan yang terkategori Amat Sangat Berat sepanjang 17,15 km atau kurang lebih sebesar $51 \%$ dari panjang pesisirnya, sedangkan kategori Amat Berat adalah sepanjang 3,55 km atau sebesar $10,5 \%$ dari total panjang pesisirnya. Pesisir yang mengalami kerusakan dengan kategori $R i$ ngan, yaitu sepanjang 11,8 km (Tabel 1). Secara keseluruhan, pesisir di Kabupaten Subang dapat dikategorikan dalam keadaan kerusakan yang sangat tinggi (Gambar 15).

Tabel 1. Tingkat kerusakan pesisir di Kabupaten Subang, Jawa Barat.

Table 1. Damage severity levels insubung district shoreline, West Java.

\begin{tabular}{lcc}
$\begin{array}{c}\text { Tingkat } \\
\text { Kerusakan }\end{array}$ & $\begin{array}{c}\text { Panjang } \\
\text { Kerusakan(fyn) }\end{array}$ & $\begin{array}{c}\text { Persentase } \\
\text { Kerusakan (\%) }\end{array}$ \\
\hline Amat Sangat Berat & 171 & 51 \\
Amat Berat & & 10,5 \\
Berat & 0,8 & 2 \\
Sedang & & 1,5 \\
Ringan & & \\
& &
\end{tabular}

- Dári paparan hasil penelitian dapat diambil beterapa kesimpulan:

Aselama tahun 1996 sampai dengan 2010, secara Keseluruhan pesisir di Kabupaten Subang me- ngalami akresi rata-rata sejauh $686,53 \mathrm{~m}$, dengan rata-rata akresi pertahun sebesar 49,04 $\mathrm{m}$, sedangkan akresi maksimalnya sebesar 1051,55 m.

- Abrasi yang terjadi di Kecamatan Blanakan, Sukasari dan Legon Kulon dalam kurun waktu 1996-2010 berkisar 565,63 m, dengan rata-rata abrasi pertahun sebesar 40,4 m. Abrasi maksimal yang terjadi sejauh 1206,83 m. Abrasi terjadi oleh karena perubahan hutan mangrove menjadi tempat aktivitas manusia.

- Garis pantai pada transek D di Desa Anggasari menunjukkan keadaan yang relatif stabil, hal ini terjadi oleh adanya kerapatan hutan mangrove yang cukup tinggi.

- Pergeseran garis pantai yang terjauh di Kabupaten Subang, baik abrasi ataupun akresi, memperlihatkan korelasi yang tinggi antara pertambahan tahun dengan gerak maju atau mundur garis pantai.

- Secara umum tingkat kerusakan di pesisir Kabupaten Subang tergolong pada kondisi rusak parah dengan tingkat kerusakan lebih dari 50\% dari total panjang pesisirnya. 


\section{DAFTAR PUSTAKA}

BAPPEDA Provinsi Jawa Barat. 2007. Laporan Akhir Atlas Pesisir dan Laut Utara Jawa Barat. Bandung.

BPS dan Bappeda Kabupaten Subang. 2005. Kabupaten Subang dalam Angka 2005. Subang.

Lillesand T and Kiefer W. 1994. Remote Sensing and Image Interpretation, John Wiley \& Sons, New York , p.750.

Novianty R, Sastrawibawa S, dan Prihadi DJ. 2011. Identifikasi Kerusakan dan Upaya Rehabilitasi Ekosistem Mangrove di Pantai Utara Kabupaten Subang. Jurnal Akuatika Vol.2 (2): 160-168.
Saskiartono O. 2008. Penataan Wilayah Pesisir Kabupaten Subang. Jurnal Perencanaan Iptek Vol.6 (2): 28-35.

Thieler E, Himmelstoss W, Zichichi L, Ayhan E. 2008. Digital Shoreline Analysis System Version 4.0-An ArcGIS extension for calculating shoreline change: U.S Geological Survey Open-file Report 2008 (Online). pubs.usgs.gov/of/ 2008/1278.

Vina AN, Taofiqurohman A, dan Koswara B. 2011. Analisis Kerentanan Pesisir Pantai Kabupaten Subang Jawa Barat. Jurnal Perikanan dan Kelautan Vol.2 (3): 9-14.

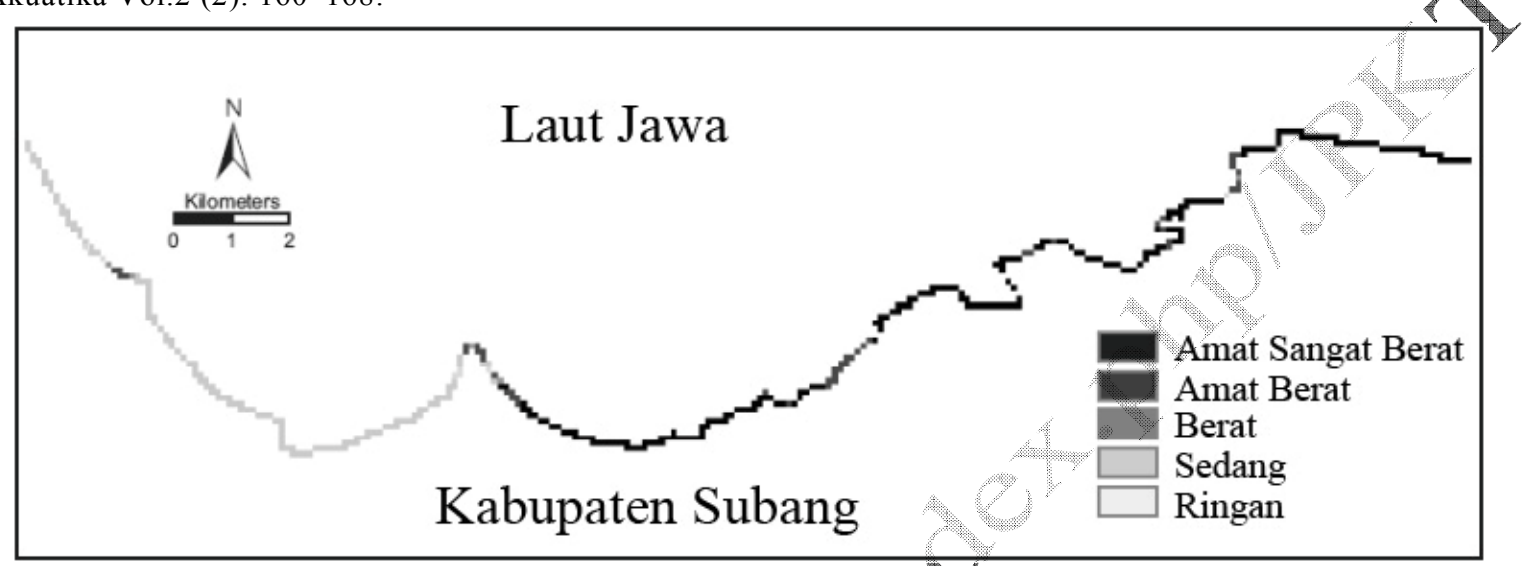

Gambar 15. Tingkat kerusakan pesisir di Kabupaten 8ubang

Figure 15. Damage severity levels in Subang shoreline.

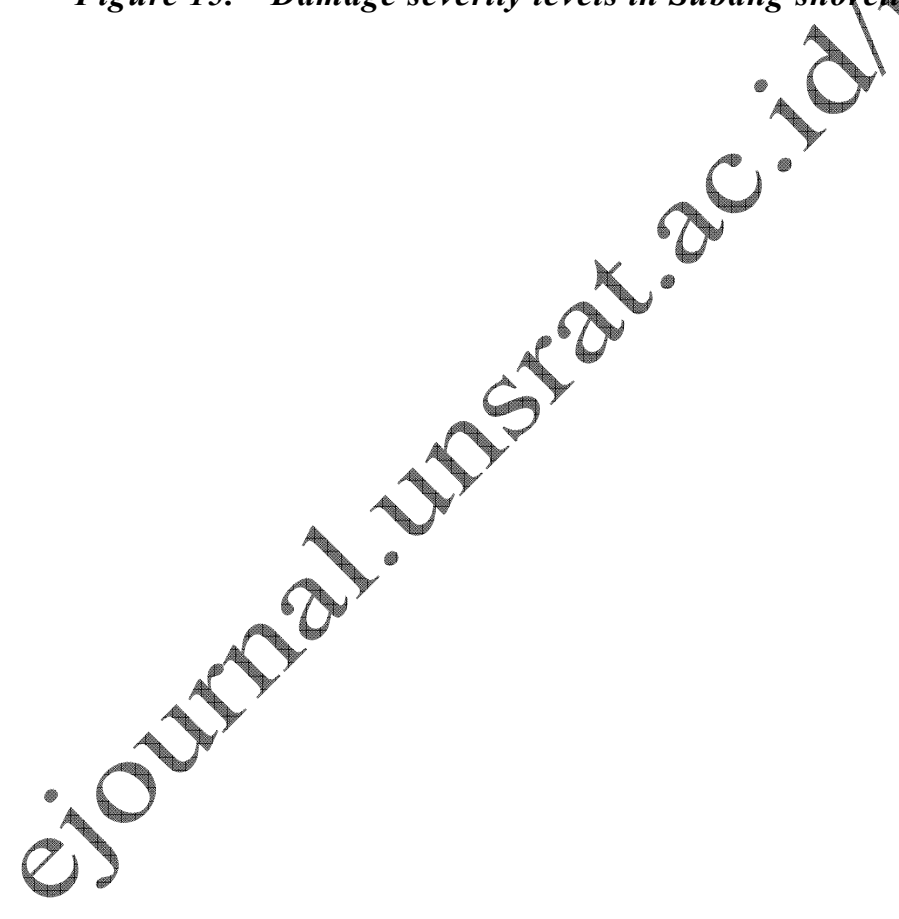

